\title{
STRONG, WEAK AND AVERAGE LINGUISTIC PERSONALITY IN COMMUNICATIVE-PRAGMATIC AND LINGUOCULTUROLOGICAL ASPECTS
}

\author{
Olga A. Kadilina ${ }^{1}$, Elena N. Ryadchikova ${ }^{2}$ \\ ${ }^{1}$ RUDN University \\ 6, Miklouho-Maclay st., Moscow, 117198 \\ ${ }^{2}$ Kuban State University \\ 149, Stavropol st., Krasnodar, 350040
}

\begin{abstract}
The goal of this research is to elicit the list of linguistic, pragmatic and cultural parameters that characterize strong linguistic personality and on the other hand week linguistic personality along with generalized average linguistic personality and to define their verbal behavior during verbal communication. In this regard, it is necessary to define individual stylistic characteristics for a strong linguistic personality; to determine skills and knowledge for a strong linguistic personality taking into consideration unique interpersonal and intercultural communication; to review the national, cultural specifics for the strong linguistic personality who belongs to English-American speech culture; to reveal the motives leading to formation of the English-speaking strong linguistic personality; to analyze the communicative problems of the weak linguistic personality. The aspects mentioned above have determined the fact that in our study we refer to such issues as parameterization and linguistic personality behavior in the field of interpersonal and intercultural communication, the search for the people's talk exchange optimum alternatives. The contexts from D. Carnegie books are the illustrative material of our article.
\end{abstract}

Key words: communicative personality; strong linguistic personality, week linguistic personality, average linguistic personality, communicative competence, interpersonal communication, influence, idiostylistic parameters, communicative leadership, national and cultural specifics

\section{INTRODUCTION}

Linguistic personality study is one of the most relevant issues in modern linguistics. The reason to address to this topic is that "linguistic personality issues are - "eternal" [1. P. 9].

As E.A. Dryangina notes, "the ideas that cover this notion were presented in the works of V.V. Vinogradov ["On fictional prose"], Slavcho Petkov ["Language and personality"], and R.A. Budagov ["Man and his language"]. However, there is no performance of a substantial integral linguistic personality as a communicative entity in any of the works given below" [2. P. 219].

Many scientists place a particular focus on the fact that these problems need extensive analysis. V. Von Humboldt also spoke about the enormous influence of language on a person: "A man is a man only because of the language... there are no thoughts without language, human thinking becomes possible only thanks to language" [quoted in: 3. P. 97]. Currently, linguists pay significant attention to the study of this 
influence. At the end of the twentieth century, scientists ascertained the fact that we are witnessing a transition from language linguistics to communication linguistics. Therefore, there was an urgent need to study "the linguistic ability of the ideal speaker/listener, his language skills, his competence" [4. P. 18].

The linguistic personality is the study focus for many linguists. This term is considered to be "the core system-forming philological concept, nowadays evaluated as integrative, which set the stage for the new milestone in linguistics development anthropological linguistics. A linguistic personality is a cross-cutting idea that strikes all the language learning aspects" [5. P. 439].

The activity principle of understanding and explaining linguistic phenomena put forward the personality idea as the center of linguistic paradigm, significantly changing the accents alignment in its description: along with the creation of native speakers' theoretical models, the communicative activity aspect of the linguistic personality study is becoming increasingly important.

This should be done in both theoretical and applied aspects. As far as in the recent past the emphasis in our country was placed on the universal, mass, average, so "the prospects of modern society development suggest that personality traits of each person are becoming essential. Availability of highly skilled specialists in any field becomes vital, and the emphasis is put on the requirements to raise intellectual level for every member of the society. Apart from this, as things go nowadays a high command of the speech art is directly related to the level of income for representatives of many professions: it greatly depends on the ability to attract and retain customers, make deals, reach agreements. It goes without saying, professional knowledge is not the only thing needed here, a common speech culture, personal charm are also required [which is fashionably called charisma], a certain image" [6. P. 19]. Along with that, we must not forget that the cultural, scientific and economic contacts of different countries and their peoples, which have sharply increased in our time, inevitably put a premium on the communicative approach to learning, because it contributes a lot to the understanding and cooperation of people from different cultures.

In recent years, linguists have been actively solving the problem of studying a language personality in general and a strong language personality in particular. However, there are very few studies devoted to the parameterization of a weak linguistic personality: firstly, in everyday life, a weak linguistic personality seems to be generalized - this is the one who "speaks poorly", "makes mistakes"; secondly, in the scientific understanding of a weak linguistic personality a priori, it is considered to be simply the one who does not possess signs of a strong linguistic personality. Nevertheless, it is widely known, that in order to successfully fight an enemy, you need to know him well, therefore it is necessary to study the main characteristics of a weak linguistic personality more clearly, specifically and in detail. This is significant because, unfortunately, those who can be called a "weak linguistic personality" are now, much more observed than in previous centuries. "With the scientific and technological progress, the media, when the person's speaking functions become less in demand compared to all the previous centuries of human civilization, especially as a result of the narrow range of people's 
direct communication, the linguistic personality in developed countries takes more passive, comfortable observer's position. Even creative human activity now does not require the involvement of all personal qualities on such a scale as it was necessary before. Apparently, this tendency is an ambiguous notion "double-edged sword": on the one hand, there are more opportunities for the development of highly specialized knowledge and skills, but on the other hand, an eloquent expression of Kozma Prutkov that a narrowly focused specialist is like a flux has not lost its relevance. Focusing on the cultivation of one thing, a person ceases to be self-sufficient, loses the harmony of development and appearance aesthetics. The most important thing is that the ease and simplicity of communicating with people of another specialty, is lost, because these skills simply do not develop, and, as you know, everything that does not develop begins to degrade over time and can atrophy at all" [6. P. 19].

G.G. Infantova put forward the following assumption. Due to the fact that "strong linguistic personality" concept has "come into official scientific use, and ... this concept in modern linguistic methods has a practical aspect which is important for all its levels, its scientific understanding is necessary as much as the definition of its parameters and introduction to the general linguistic context, correlation with other concepts of speech character" [7. P. 64]. So much more it is important "since the problem has just been adumbrated on general issues concerning the anthropocentric approach to the language study and on private issues; speech portraits of the different cultures native speakers has not been published yet, there is still no complete clarity in the very typology of speech cultures, many concepts related to the problem "language and personality" are not clearly defined. This could be applied, in particular, to the concept of "strong linguistic personality" [ibid. P. 64]. Moreover, although Dale Carnegie said, "personality is something vague and elusive, not amenable to analysis, like the smell of violet" [8. P. 384] because of its complexity and multiformity, it is necessary to take steps in this direction.

For modern science, the interest is no longer just a person in general, but a personality, i.e. a specific person, a carrier of consciousness and language, possessing a complex inner world and a definite attitude towards fate, material world and other people.

At this point, a global, interdisciplinary approach to the interpretation of the language essence has been formed as a specific human phenomenon, through which one can understand the nature of a person, its place in the society and ethnicity, its intellectual and creative potential, i.e. think deeper what a person is [9. P. 103].

\section{THE HISTORY OF THE "LANGUAGE PERSONALITY" PHENOMENON STUDY}

The term "linguistic personality" was first used by V.V. Vinogradov in 1930. "The word personality, which has a bright coloring of the Russian national-language cogitative system, contains elements of international and, above all, European understanding of the corresponding volume of ideas and concepts about man and society, about social individuality in its relation to the collective and the state" [10. P. 271]. 
G.I. Bogin suggests a linguistic personality ${ }^{1}$ should be displayed as a person with idiomatic speech, who has the ability to use the language system in his activity at large [11. P. 3]. There is a similar understanding given by Y.N. Karaulov: "A linguistic personality is a personality expressed in language [texts] and through language, it is a personality reconstructed in its main features on the language means basis" [12. P. 38].

The study of linguistic personality is currently multidimensional, large-scale and involves the data from many related sciences. Many scientists speak of a multi-layered, multi-level linguistic personality.

V.V. Krasnyh summarizes the "personal" phenomena, enclosed in the concepts of "a man speaking", "linguistic personality", "verbal personality", "communicative personality", in the definition of "man speaking", the content of which appears as "a personality phenomenon complex — as a linguistic, verbal and communicative personality" [13. P. 160]. However, it occurs that the concept of a "man speaking" is a little narrower compared to the term "communicative personality", since speaking is a one-way process, implying only the ability to produce speech, while communication is a two-sided and multilateral process involving more knowledge and skills connected to the impact on the interlocutor and tracking this impact.

Undoubtedly, Dale Carnegie [1888 - 1955] was an outstanding linguistic personality - a native speaker of English, an oratory and culture of speech communication promoter of the twentieth century. He "created a one-of-a-kind learning system an amazing comprehensive course covering the practice of public speaking, the art of persuading, relationships problems between people, and applied psychology" [14. P. 32].

The linguistic personality is a social phenomenon, but it also has an individual aspect. The imprint of individuality must be present in every speech. The author's linguistic identity is necessarily represented in one way or another and so, accordingly, could be easily followed in the text composed. Each linguistic personality is formed because of a certain person's appropriation of all the linguistic wealth created by the predecessors.

The language of a particular personality consists to a greater degree of a common language and to a lesser degree - of individual linguistic features. However, these features precisely can sometimes play a decisive role in speech utterance and have the impact on the associates.

While describing this D. Carnegie, cites the lectures of two aviators who made the first flight from London to Australia as an example:

"They had identically the same experience, they had sat side by side as they flew halfway around the world, and they delivered the same talk, almost word for word. Yet somehow it didn't sound like the same talk at all. There is something beside the mere words in a talk which counts. It is the flavor with which they are delivered" [15. P. 197].

${ }^{1}$ As for the term «linguistic personality», as V.V. Krasnykh notes, it was introduced into everyday scientific lexicon by Y.N. Karaulov; although many scholars consider G.I. Bogin to be the author of the term, who introduced and substantiated this concept in his doctoral dissertation in 1984 in «The Model of a Linguistic Personality and its Relation to Varieties of Texts» [see 13. P. 148-149]. 
N.D. Golev proposes to designate the term "anthropotext" [16. P.15] as the text that manifests the properties of a linguistic personality [16. P. 15]. There is every reason to attribute the books of D. Carnegie on the art of verbal communication to the category of anthropotex.

The human speech is affected by many constant and variable factors that made it possible to create linguocultural types. There are certain prerequisites for constructing a person's speech portrait based on lexical-grammatical, cognitive and intentionally interactive levels of personality discourse. Our research is carried out in compliance with the first of this thesis - in the aspect of ideolecticism, for which it is important to take into account linguistic factors, their understanding and interpretation.

The linguistic personality should not be considered as something indiscrete, but one should produce a certain gradation, create a hierarchy of its types, qualify the types of linguistic personality according to the signs of strength and weakness manifestation depending on their ability to produce and analyze a verbal behavior. Linguistic personalities modeling based on linguistic criteria turned out to be possible built upon discursive parameters, so it reflects sociocultural conditions to a large extent, as well as psychological variables. Y.N. Karaulov identifies three levels of linguistic personality: verbalsemantic, linguistic-cognitive (thesaurus) and pragmatic (or motivational) [12. P. 5].

\section{CLASSIFICATIONS OF LINGUISTIC PERSONALITIES}

There is a number of classifications of linguistic personalities in modern linguistics. The classification of linguistic personalities seems to be the most accurate, if it includes three components: 1) a weak linguistic personality; 2) average linguistic personality; 3) strong (elite) linguistic personality. This classification allows you to select the main criteria, characteristics and abilities of each of these types. The same talk given on behalf of a weak, medium and strong linguistic personality will differ.

\subsection{Average language personality}

The concept of an average native speaker in linguistic literature has not been defined yet; the knowledge of his national and cultural issues has not been fully described in a language.

Possibly, dealing with the "average" native speaker does not cause much zeal in domestic linguists, not only because of the fact that the boundaries and the criteria of such a person are vague, but also because "in the Russian language the mediocrity, being average, the lack of clear individual features are perceived as negative. In the cultural-linguistic society of the Russian language speakers, the qualitative uncertainty of a person is negatively evaluated - inconsistency, instability of its value-motivational structure" [17. P. 189]. In this case, the semantic dominant of a person is mediocrity and inability to create. From our point of view, the concept of average linguistic personality does not imply "semi-literacy", but full literacy, albeit without much skill. The average linguistic personality — unlike the artist in words - can be characterized by simple regularity of speech and nothing more. In interpersonal verbal communication, the averaged linguistic personality, as a rule, does not think about oratorical skills, about 
the impression the words make, about the comfort of communication, about the methods and means of helping to gain and retain the interlocutor's attention.

Let us give an example:

"In the process of getting and holding audience, which is the first purpose of every speaker, there is one aid, one technique, that is of the highest importance. Yet, it is all but ignored. The average speaker does not seem to be aware of its existence. He has probably never consciously thought about it at all. I refer to the process of using words that create pictures. The speaker who is easy to listen to is the one who set images floating before your eyes. The one who employs foggy, common-place, colorless symbols sets the audience to nodding" [15. P. 82].

However, studies show that the average linguistic personality, which is characterized only by the simple correctness of speech, is evaluated by native speakers mostly negatively - as mediocrity, being incapable to create, to conduct interpersonal communication correctly.

In interpersonal verbal communication, the average linguistic personality, as a rule, does not think about the oratorical skills, what impression their words make, about the comfort of communication, about the methods and means of helping to gain and retain the interlocutor's attention. D. Carnegie describes such a person as follows:

"You want the approval of those with whom you come in contact. You want recognition of your true worth. You want a feeling that you are important in your little world. You don't want to listen to cheap, insincere flattery, but you do crave sincere appreciation. You want your friends and associates to be, as Charles Schwab put it, "hearty in their approbation and lavish in their praise." All of us want that. So let's obey the Golden Rule, and give unto others what we would have others give unto us. How? When? Where? The answer is: All the time, everywhere" [15. P. 82].

\subsection{Strong linguistic personality. Characteristics of a strong linguistic personality}

The concept of "strong linguistic personality" in rhetoric as the art of logical reasoning and verbal communication usually includes: 1) fundamental knowledge possession; 2) the presence of a rich information stock and the desire to replenish it; 3) mastering the basics of constructing speech according to a certain communicative concept; 4) speech culture [the idea of speech forms corresponding to the communicative plan] [18. C. 12].

The 1990s stand out for the dissertation research and articles with speech portraits of individual native speakers, possessing an elite speech culture. For the understanding of such objects the principle of intellectualism is especially significant.

Summarizing the views of these scientists, and relying on the opinion of G.G. Infantova [7], we believe that the characteristic signs of a strong linguistic personality should include extralinguistic (social personality characteristics, extra linguistic awareness, sense of humor and the relevance of speech communication awareness) and linguistic indicators - language and speech. They can be constant and variable.

A strong linguistic personality must know and skillfully apply the whole range of linguistic means that enrich and adorn the speech - comparisons, contrasts, meta- 
phors, synonyms, antonyms, paremias, aphorisms, word-symbols, etc. An indispensable condition for a strong linguistic personality is a highly developed intellect, creativity.

Strong linguistic personalities could be found in all social strata. However, most of all, this verbal type is common among the intelligentsia.

The process of communication is a prerequisite for identifying the parameters of a linguistic personality and its characteristics.

In modern linguistics, it is customary to distinguish between linguistic and communicative competences. To achieve success in communication, especially in the professional field, it is necessary to have a high level of communicative competence. It assumes, along with other factors, mastering the culture of speech, i.e. mastering the norms of oral and written literary language (rules of pronunciation, stress, word usage, grammar, stylistics), as well as the ability to use language expressive means in various conditions of communication in accordance with the objectives and speech content.

The ability to compose texts purposefully and competently that meet the pragmatic conditions of communication, stylistically and situationally relevant, expressive; the ability to understand hidden meanings, subtext and use it in one's own speech; the ability to adequately assess the specific situation of verbal communication and to implement the appropriate model of verbal communication, true in ethical and aesthetic terms could be considered as characteristic skills of the highest level of speech ability for the linguistic personality.

Thus, a strong linguistic personality possesses not only correct, but skillful, masterful speech, which has a creative aspect associated with the surface and deep structures' transformation, the ability to direct expressiveness to non-expressive word forms. Suggestive potential and adaptability are among the indicators of a strong linguistic personality.

In interpersonal communication, this a person is able to apply appropriate language functions and their combinations, communication strategies and tactics and can protect itself from demands, requests, encroachments that infringe upon its interests, create a positive image, exercise reflection, show charm, maintain contact with the audience, calculate proximate and distant goals of communication, the interlocutor's reaction to the statement, status-situational roles, the status and the interaction between partners due to the alternate participation in the conversation.

Language analysis of D. Carnegie's works revealed the following signs of a strong linguistic personality in interpersonal communication: the ability to evoke listeners' emotions, appealing to their feelings, to saturate speech with emotional power; honesty, truthfulness, concreteness, sincerity, interest, enthusiasm and deep conviction; ability to enthrall listeners with its impulse; the thorough understanding of the interlocutor, a kind of penetration into his personality, plans and motives of speech; the ability always to speak calmly, very gently and very friendly, not allowing any pressure and coercion. Often, an open self-criticism is a shock absorber that can relieve tension in a dialogue, promote successful, conflict-free speech communication. It seems that these qualities, knowledge and skills can be considered universal.

To succeed in convincing the negative interlocutor Carnegie welcomes the use of the following tactics: apology, a few compliments, a soft request, justified with the help 
of a compliment, an expression of complete trust, elevation of the interlocutor, giving him the right to choose, showing respect to his choice.

In the process of interpersonal communication, the ability to influence the audience is one of the clearest signs of a strong language personality. Since there is no universal remedy to satisfy the desired addresser, it is necessary to analyze the process of communication, reflect on it constantly and every time to decide anew how, when and in which combination to apply the rules of verbal communication.

For a communicative personality, the characteristics of the three main parameters - motivational, cognitive and functional - are decisive. The success of interpersonal communication for a developed communicative personality is achieved because of its ability to communicate clearly and accessibly to the addressee, to report, analyze, comment, summarize, parry, generalize, predict, which implies a developed mental apparatus; as well as avoidance of self-confidence, adherence to the principles of cooperation, partnership, courtesy and common culture - the presence of composure, emotional non-response to the interlocutor's attacks.

The concepts "strong personality" and "strong linguistic personality" are not directly related, the first quality does not predetermine the second.

In this regard is D. Carnegie offers an interesting example:

"The man with the degree was a college professor; the ex-tar was the proprietor of a small side-street trucking business. His talks were far better received by the class than those given by the professor. Why? The college man used beautiful English. He was urban, cultured, refined. His talks were always logical and clear. But they lacked one essential concreteness. They were vague and general...The trucking firm proprietor's language was definite, concrete and picturesque... The virility and freshness of his phraseology made his talks highly instructive and entertaining” [15. P. 65-66].

A clear distinction between the concepts of "linguistic personality" and "communicative personality" seems to be of little consequence, we regard them as largely intercross concepts. We believe that the concept of "communicative personality" is closer to the interpretation of the definition of a strong linguistic personality, rather than to the term "linguistic personality". In this case, we rely on the following arguments. Categorical signs of a linguistic personality in relation to speech actions are their creation and perception, and for a communicative person it is also necessary to create conditions for successful communication, efforts to track its functioning and impact on the interlocutor, feedback from the interlocutor, including reading non-verbal signs, checking relevant feedback, adjustment in case of failure to achieve the goal of communication, etc. For a developed communicative personality, it is necessary not only to be able to speak, but to communicate, report, parry, summarize. In this regard, as noted by O.V. Ledeneva, in addition to communicative skills, it is advisable to develop gnostic, design, and constructive skills. "So, the gnostic (cognitive) skills are the ability to single out the main thing, formulate hypotheses, produce analysis, synthesis, generalization. Design skills involve the formation of goals, the result of speech. Constructive skills are associated with drawing up a plan, theses of the forthcoming message and include the ability to draw conclusions, generalizations [19. P. 122]. These knowledge and skills are considered the prerogative of not only the communicative personality, but also a strong 
linguistic personality. These skills allow you to create your own judgments, develop a person's thinking apparatus, therefore, contribute to the development of a strong linguistic personality.

In relation to the use and understanding of humor, a strong linguistic personality indicator is a skillful language game (delicate use of style contrast, metaphors and metonymy, irony, periphrastics, comparison, etc.), whereas for an average and weak linguistic personality this plan is characterized by a reduced language game, witty talk.

Undoubtedly, harmonious interpersonal communication, to which aspires a strong linguistic personality, is usually built taking into account the principles of cooperation, cooperation, politeness and common culture - here the non-categorical form of presentation of thought, underlining courtesy, softening sharp characteristics, caution, certain distance, underlining some share of doubt, avoiding abrupt characteristics or excessive straightness, perseverance, direct or implicit apology of the speaker for the possible unpleasant effect of his words, where the circumstances compel him [20. P. 132]. D. Carnegie shows the following:

"If a man's heart is rankling with discord and ill feeling toward you, you can't win him to your way of thinking with all the logic in Christendom. Scolding parents and domineering bosses and husbands and nagging wives ought to realize that people don't want to change their minds. They can't be forced or driven to agree with you or me. But they may possibly be led to, if we are gentle and friendly, ever so gentle and ever so friendly" [21. P. 100].

"This speech, in its entirety, is a masterpiece. It produced astonishing results It calmed the tempestuous waves of hate that threatened to engulf Rockefeller. It won him a host of admirers. It presented facts in such a friendly manner that the strikers went back to work without saying another word about the increase in wages for which they had fought so violently" [21. P. 99].

The criteria of the most effective result of interpersonal communication can be recognized as genuine communicants' mutual understanding and joy, communicative comfort, intellectual, emotional and aesthetic empathy. Possession of such communicative universals and their appropriate use in interpersonal communication makes linguistic personality strong. In linguistics, there is also the concept of communicative leadership. In our opinion, it is close to the concept of a strong linguistic personality. "A communicative leader is a person who possesses non-trivial information from in a given communicational situation, who knows how to express this information in the most effective way and bring it to the addressee through optimal language contact" [22. P. 30]. Of course, assertiveness and imperiousness in speech communication do not always contribute to favorable communication. For example, Benjamin Franklin noted: "The modest way of expressing opinions led to their being accepted and they caused less objection" [quoted from 8. P. 146-147].

D. Carnegie - gives a number of positive examples regarding successful communication leaders - politicians and lawyers. Here is one of them:

"No bulldozing. No high-pressure methods. No attempt to force his opinions on others. Webster used the soft-spoken, quiet, friendly approach, and it helped to make him famous" [21. P. 101]. 
In addition to the strong linguistic personality of the addresser, there is also a strong linguistic personality of the addressee - one that is capable of fully accepting everything that the author of the speech implies, and [mostly in the case of a literary text] to enjoy it.

In the intercultural communication implementation, knowledge and skills of a strong linguistic personality primarily lie in the area of vocabulary, functional grammar, structure and concept sphere of the language in which communication takes place, in the field of the ability to understand and apply the stylistic-discursive and etiquette specificity of different languages, which should manifest itself in conditions of tolerance, openness and readiness to communicate with a foreign language speaker. It is important to cover the full range of cultural information contained in the language as in the idiom. At the same time, the focus is on pragmatic skills, including background cultural knowledge command and cultural studies, adherence to social norms and speech etiquette of foreign culture representatives, body language practices, silence and context, along with cultural sensitivity or susceptibility, cultural adaptation, and avoidance of ethnocentrism.

Since the main goal of intercultural communication is mutual understanding, so participation in intercultural communication contributes to the person's "cognitive flexibility" and enhances the ability for analytical thinking, intercultural and linguoculturological competence.

\subsection{Weak linguistic personality and its characteristics}

A weak linguistic personality acts both as an author and as a recipient of speech and can manifest itself at almost all speech-communicative levels.

Weak linguistic personality is characterized by such idiostyle parameters:

a) at the linguistic level - ignorance of the norms and various styles and genres of language and speech, forms of speech etiquette, speech poverty, lexical composition monotony, the presence of many hesitations, a large number of parasitic words, empty sounds that have no meaning, which indicates a poor word-stock, officialese, use of words and phrases in unusual meanings, inability to comply with the rules of language games, replacing them with a primitive jest, excessive use of foreign words, the use of vulgar, obscene, abuse, ridicule, carping indiscriminately, non-use of praise and approval;

b) at the communicative level — the inability to convince, the inability carry on a conversation in a right way, the inability to listen to the interlocutor and defend one's point of view, logical inconsistencies, the fear of communication and the tendency to avoid it, lack of interest, self-reliance, inability to distinguish situations requiring the use of suggestives and directives, the inability or unwillingness to hide negative attitudes in communication, inappropriate speech tactics, demonstration of intelligence and protection, flattery and taffies, narcissism, swagger, quarrelsome disposition, the absence of even hints of self-criticism, one's behavior, one's speech, disrespect for the addressee, an expression of contempt towards the listeners. The "weak" speech tactics can be attributed to The desire to argue, defending their case by all means, and the so-called "righteousness", that is, the desire of the speaker to "denounce" the inter- 
locutor in mistakes and can be attributed to the "weak" speech tactic. In such cases, D. Carnegie is utter in negative evaluations; he very emotionally warns against mistakes:

«Never begin by announcing "I am going to prove so-and-so to you”. That's bad. That's tantamount to saying: "I'm smarter than you are, I'm going to tell you a thing or two and make you change your mind".

That is a challenge. It arouses opposition and makes the listener want to battle with you before you even start» [21. P. 120].

Even an elitist speech can characterize a weak linguistic personality due to the lack of addressing of speech [see, for example, 23. P. 226].

D. Carnegie gives a remarkable example:

"Edmund Burke wrote speeches so superb in logic and reasoning and composition that they are today studied as classical models of oratory in the colleges of the land; yet Burke, as a speaker, was a notorious failure. He didn't have the ability to deliver his gems, to make them interesting and forceful; so he was called "the dinner bell" of the House of Commons. When he arose to talk, the other members coughed and shuffled and either went to sleep or went out in droves" [15. P. 205].

c) at the paralinguistic level-aggressive tone, unpleasant voice, lack of ability to read kinetic information, stiffness, restraint, noisiness or lack of loudness and emotionality of speech, monotony, fussiness, cynical and excessively offensive listening, inappropriate gestures and gestures that do not cause facial expression, glance, intonation, manner of presentation;

d) at the mental and intellectual level: constricted outlook, the need to make constant intellectual efforts during communication in order to understand and get the meaning conveyed by the addressee, the inability to take into account the situation of discourse and topics for communication.

In our country, there are cases when "even grown-up, fully-fledged specialists with higher education do not know the forms of speech etiquette [even simple clichéd forms like greeting, sympathy, congratulation, compliment, etc.], have no manner to communicate with older by age and position [including by phone], do not consider it necessary to simply listen to another person, do not know how to read kinetic information.

They are afraid or do not know how to resist the impolite and rude opponents. This leads to stiffness, tightness, fear and avoidance of communication, the inability to talk in the right way, calmly and with dignity to defend their point of view, and even simply to present it in a form accessible to other people, fraught with conflicts with management and customers" [6. P. 20].

This echoes the observations of D. Carnegie over the Americans:

"And the pathetic part of it is that frequently those who have the least justification for a feeling of achievement bolster up their egos by a show of tumult and conceit which is truly nauseating" [21. P. 160].

A weak linguistic personality considers itself smarter and more significant than others. In turn, other people avoid this person, ignore him, laugh at him behind his back, or even despise, consider a fool; he may be downgraded.

When carrying out interpersonal communication, children, foreigners and the sick are recognized as weak linguistic individuals in any community. 
The problems of a weak linguistic personality are not only its problems in interpersonal and intercultural communication. These are, first of all, the problems of the individual, his life in society: pride, an inferiority complex, being obtuse, excessive self-conceit, aggressiveness, no intention to develop spiritual and moral qualities and special qualifications, inability to accept someone else's opinion, fear of being wrong and therefore weak, unsuccessful.

Unfortunately, those who can be called a weak linguistic personality, are currently observed much more than in previous centuries [6]. Weak linguistic personalities are often those who, by virtue of their professional activities, must not be so. Thus, not only in Russia, but in many other countries, aggressive verbal acts often serve as means of influencing and educating children in schools. At the same time, a teacher using these methods is perceived negatively, as a weak professional and as a bad person. Research carried out in this aspect by Professor F. Kiner, the University of Göttingen, confirmed this; most of the students surveyed by him answered that 'the reason for the teacher's scolding is his own shortcomings [topic ignorance, general irritability, poor attitude towards a particular student, etc.]. Aggressive verbal behavior of the teacher, therefore, is not perceived by students as an intention to correct their shortcomings. The teacher, as a person who plays a certain social role, loses respect of pupils due to the use of verbal aggression acts" [24. P. 159].

We need in constant speech improvement. D. Carnegie suggests that any speaker can carefully follow the rules and patterns of constructing public speech, but still can make many mistakes. He can speak in front of the audience exactly as in a private conversation, and at the same time speak in an unpleasant voice, make grammatical mistakes, be awkward, behave insultingly, and perform many inappropriate acts. Carnegie suggests that every person's natural, everyday manner of speaking needs many corrections, and it is necessary to first improve the natural style of conversation and only then to transfer this method to go up to the rostrum [8. P. 381-382].

In intercultural communication, it is also possible to detect manifestations of a weak linguistic personality. They are subjective and objective. Subjective manifestations: the interlocutors have a poor command of the language, are not inclined to mutual understanding, do not take into account the specifics of the situation, build their verbal and nonverbal behavior on the basis of various cultural axioms. Objective manifestations: the difference between the "national consciousness" of communicants, the divergence of cultures, the different division of the conceptual space, the goals and strategies of communication.

The linguistic personality is not only a social phenomenon that has, in addition to universal, national and cultural components, but it also has individual aspects.

A number of modern scientists devote their research to the problem of identifying a universal and national-specific language personality, noting that a personality should be viewed in the cultural tradition perspective of a people, ethnic group, because for the genesis of a person in a human being there is a need of a cultural-anthropological prototype, which is formed within the culture. Therefore, linguists are paying more and more attention to the problem of national character. 
Successful use of national cultural semantics in speech is largely determined by the national stereotype existence in the field of speech communication: "It is not possible to draw a parallel between a linguistic personality and a national character, but there is still much in common between them..." [12. P. 42]. That is why Y.N. Karaulov emphasizes the national character already in the very definition of a linguistic personality. In his opinion, the actual linguistic or vocabulary personality is "the basic nationalcultural prototype of a certain natural language carrier, fixed mainly in the lexical system, composing the timeless and invariant part of the linguistic personality structure" [ibid., P. 39]. A similar position is held by V.I. Karasik, P.V. Chesnokov, S.G. Vorkachev, O.A. Leontovich, A.P. Sedykh, O.S. Shiryaeva, A.M. Barminskaya, G.V. Komarov and many other scientists. Therefore, although it is possible to speak about the universalism of the linguistic personality criteria, it is nevertheless necessary to rely on certain national-cultural features, since the existence of a national stereotype in the field of speech communication has already been proven.

Grammar, vocabulary and semantics of each language have national specifics, which is largely determined by extralinguistic indicators - national specifics of mentality, historically formed stereotypes, myths, including modern ones, the most popular subjects for discussion preferences among representatives of a given nation, etc. [see 24].

We share the opinion of O.A. Leontovich, who notes that the situation for native English speakers is unique, since the linguistic personality not only belongs to the communities located close to one another, but also includes far-located states where people speak English. Thus, native English speakers share features common to all residents of English-speaking countries [25. P. 127]. Therefore, "English is the invaluable resource where it is possible and necessary to study the patterns of intercultural communication" [ibid., P. 95].

D. Carnegie believes that the most relevant topics for discussion are as follows sex, property and religion: with the first, we can create life, with the second, we support it, and with the third, we hope to continue it in another world [8. P. 458]. Despite the real importance of these topics, we still believe that they can be considered nationally specific, popular among Americans, and for people of many other nationalities these other subjects can often be other problems.

The main goal of a strong English-speaking linguistic personality manifestation is to implement the "American-centrism" suggesting that he can dictate its will to other peoples of developing countries.

O.A. Urusova states that the most characteristic social activities of America are as follows: the actor, military man, educator, player, assistant, person with authority, aggressor, lawyer, politician, partner, dictator, steersman [26]. Many of them are associated with verbal communication and make appropriate impact on it, they require certain verbal skills and abilities formation that characterize a linguistic person as a strong one.

Many etiquette forms and principles of communication are national. "Polite and etiquette People communicate politely and adhere to etiquette in different countries. But each of the national languages manifests its own specifics, because the unique features of the language here are superimposed by the characteristics of rituals, habits, 
everything accepted and unaccepted in behavior, allowed and prohibited in the social etiquette of a given nation" [27. P. 130].

For Americans, communication is characterized by simplicity, sociability, neighborliness, ease, tolerance, friendliness, honesty — it is the norm of behavior in everything in any verbal behavior, for example, it is not accepted to give false testimony in court, to violate obligations in business [28. C. 5]. American etiquette requires constant smile when communicating, demonstrating that "they have everything O'key!" In the American national tradition, it is accepted: whatever happens - "keep smiling". The question "How are you?" In this tradition requires an indispensable standard positive answer “fine!", "great!”, “all right!”, “everything’s OK!”.

Among the apparent advantages of English-speaking communication we can mention: empressement, politeness, no forceful language, awkwardness when it is impossible to fulfill the request of your interlocutor, a large proportion of phatical etiquette communication formulas; to express a request, it is usually not an imperative that is used, as, for example, in Russian, but an indirect request in the form of a direct or indirect question. The expression of surprise, distrust and similar emotions in English language is much more restrained than in Russian. Therefore, with good reason, D. Carnegie calls for meaningful, calm and polite speech actions. D. Carnegie writes: "Little phrases such as "I'm sorry for you", "Won't you please?", "Would you mind?", "Thank you" "little courtesies of the monotonous grind of everyday life - incidentally, they are hallmark of good breeding" [15. P. 101].

The provision of services to a hostile person, asking him for a service in order to earn his friendly disposition is a nationally-specific American communicative-speech tactics [Carnegie 1989, P. 246-247]. In a number of other cultures [very often in Russian], not only doing a favor to a hostile person, but also asking him for one can cause hostility and refusal to communicate. "The inability to fulfill the request of his interlocutor causes a feeling of embarrassment in native English speakers... The refusal itself must combine politeness and persuasiveness. Even in the case when the reason for the refusal is not given, the Englishman is not inclined to extort it from the interlocutor. English etiquette does not recognize categorical forms" [27. P. 131]. Apparently, because of this, in English verbal communication there are formulas of phatic etiquette communication, which are much more evident than in Russian. While expressing surprise, distrust and similar emotions in the Russian language common remarks are as follows: What do you mean! Can not be! True? Oh my God! Nightmare! Horror!, but in English — Really, Heavens, as well as grammatical structures set up according to the "auxiliary verb + pronoun" scheme, which are absent in the Russian language [29. P. 13].

Differences between Russian and English-language communication also show up in the etiquette of the request. In Russian, the imperative is most typical. In English, the most acceptable and polite form of a request is an indirect request in the form of a direct or indirect question [29. P. 17]. However, from a position of speech communication tactics, a request can sometimes do a disservice. D. Carnegie gives an example from the life of B. Franklin, who decided to gain the favor of a person hostile to him, because he could be useful to him in business. Franklin decided to gain goodwill of this man. However, not by doing his enemy a favor, but on the contrary, he asked his enemy 
to do him a favor. Franklin died more than a hundred and fifty years ago, but the psychological method applied by him retains its effectiveness by now [30. P. 246-247]. However, it seems that this tactic cannot be recognized as universal, but rather belongs to the national-specific.

Some paralinguistic phenomena can rightly be attributed to the national-specific features of a strong English-speaking linguistic personality. The brightest of them is showing a smile in all situations and the reaction of others to it [keep smiling - "keep a smile", no matter what happens]. D. Carnegie believes that a smile gives a lot to both the subject and the object of speech, enriches them, it remains in memory for a long time, it creates happiness in the house and a benevolent atmosphere in business communication, it is impossible to do without it, it is the best antidote for absolutely all troubles. The manner of speaking can also have a strong influence on an English-speaking audience, for example:

"There is an old saying in the English Parliament that everything depends upon the manner in whish one speaks and not upon the matter. Quintilian said it long ago, when England was one of the outlying colonies of Rome" [15. P. 197].

Speech does not have only an immediate goal, but also a motive - the thing for which the speech goal is achieved. "Without understanding the motive of verbal actions, we cannot fully understand the meaning of the statement. Thus, any activity [including speech] is a process guided and prompted by a motive - in which this or that ability is "objectified" [31. P. 57]. C.O. Malevinsky even considers it necessary to include motivational and speech predispositions in the speech structure of the personality [32. P. 128]. We share this point of view.

The study of D. Carnegie's language allows to identify the following motivational reasons in order to become a strong linguistic personality in the English-speaking environment:

1) prestige, the importance of being and positioning oneself as a strong linguistic personality for almost all layers of society:

"These investigations revealed that even in such technical lines as engineering, about 15 percent of one's financial success is due to one's technical knowledge and about 85 percent is due to skill in human engineering — to personality and the ability to lead people" [21. P. 16];

2) demand for a strong linguistic personality in business and everyday communication:

"But gradually, as the seasons passed, I realized that as sorely as these adults needed training in effective speaking, they needed still more training in the fine art of getting along with people in everyday business and social contacts" [21. P. 15];

3) receiving high wages, large incomes, expansion of production, commercial success:

“This training... brought him a promotion with increased pay" [21. P. 18];

4) the desire for leadership, the desire to stand out, to be seen among many other people, maximum heights (achievements) on the career ladder, influencing others, selfpromotion; 
5) shortcomings of the educational system of America (at least until the second half of the 50 s of the twentieth century):

"He had learned more in fourteen weeks through this system of training about the fine art of influencing people than he had learned about the same subject during his four years in college" [21. P. 21].

"The fact that in ten - twelve years after the end of primary and secondary school or college, these people take a similar course of study (of elocution oratory) is a clear evidence of the glaring errors of our education system" [14. P. 22];

6) the desire to get rid of the verbal communication fear;

7) improvement of intrapersonal self-perception and family relations:

"Spouses... have told me that their homes have been much happier since their husbands or wives started this training" [21. P. 20];

8) the desire to look decent in the eyes of others, consistent with the image of a cultured person;

9) the desire for lifelong self-improvement.

"At the end of the course, students organize their own clubs and for many years continue to gather for them every two weeks. In Philadelphia, one such group... has been encountered... for the past seventeen years" [14. P. 33].

A strong linguistic personality speaking English as a native language can shape the reading of certain books. D. Carnegie offers a reading program for Americans. These are the works of Byron, Milton, Wordsworth, Whitier, Shelley, St. Augustine, Bishop Butler, Dante, Aristotle, Homer, Demosthenes, Tacitus, Newton, Euclid, Hezlit, Lam, T. Brown, Defoe, Hawthorne, Montaigne, Fucidad, Laem, T. Bennett, R.W. Emerson, F. Norris, D. Hillis, W. James, A. Morois, Byron, R.L. Stevenson. The best choice are still the Bible and Shakespeare.

"An executive in the Philadelphia Gas Works Company, was slated for demotion when he was sixty-five because of his belligerence, because of his inability to lead people skillfully" [21. P. 17].

"For years, he had driven and criticized and condemned his employees without stint or discretion. Kindness, words of appreciation and encouragement were alien to his lips" [21. P. 18].

Here comes the result:

"When I used to walk through my establishment, no one greeted me. My employees actually looked the other way when they saw me approaching" [21. P. 18].

D. Carnegie calls the ability to listen to partner carefully and benevolently "an easy way to become a good conversationalist". The lack of this quality characterizes a weak linguistic personality:

"Many people fail to make a favorable impression because they don't listen attentively" [21. P. 96].

"Hire clerks who haven't the sense to be good listeners" [21. P. 100].

Carnegie gives advice "by contradiction":

"If you want to know how to make people shun you and laugh at you behind your back and even despise you, here is the recipe: Never listen to anyone for long. Talk incessantly 
about yourself. If you have an idea while the other person is talking, don't wait for him or her to finish: bust right in and interrupt in the middle of a sentence" [21. P. 106].

However, in order to be listened without interruption, it is necessary to show the qualities of a strong linguistic personality. An aggressive tone, as characteristics of the voice can prevent this. But:

"The chronic kicker, even the most violent critic, will frequently soften and be subdued in the presence of a patient, sympathetic listener - a listener who will he silent while the irate fault-finder dilates like a king cobra and spews the poison out of his system" [21. P. 92].

Even using moderate language material, it is possible in general terms to identify the main features of the three levels of a weak linguistic personality [according to Y.N. Karaulov]:

1) verbal-semantic level. Signs of a weak linguistic personality: arrogance, rudeness, aggressive tone, hostility, inability to listen to the interlocutor, abuse, criticism indiscriminately, non-use of praise and approval in communication;

2) lingvo-cognitive level. A person who is a weak linguistic personality believes that others are not as smart as he is; all they say is idle chatter, no use to waste time listening to it;

3) communicative and pragmatic level. A weak linguistic personality provokes the following feelings in others: people avoid it, ignore it, laugh at it behind their eyes, or even despise it, consider it a fool; he may be downgraded.

The manifestation of features of a weak linguistic personality may be situational, depending on a number of historically determined social factors. A situation in which a strong linguistic personality becomes weak may have psychophysiological roots, for example, emotional experience, stress, or affectation. Some students of the prestigious Harvard University oddly enough, can be attributed to the weak type of the American linguistic personality of the 50-s of twentieth century (still D. Carnegie's time) [see 33. P. 13]. Writing down a linguistic personality to a weak may have, in addition to the above, the time factor, something that was once considered a bad form, over time may cease to be so. Thus, over the course of two hundred years, the image of a gentleman in the American linguistic consciousness has undergone reconceptualization. In the United States today, gentlemen can be not only men of European appearance, but also AfricanAmericans, which was impossible in the nineteenth century.

Americans in intercultural communication can be a weak linguistic personality also when they are persistent and ask questions that others do not like to answer, especially when it comes to particular features of the country where interlocutors are coming from, their religion, politics, and wars in their homeland, about meeting people from their country. In addition, in the intercultural communication between Americans and representatives of other cultures, the stereotyping of the national image, the particular picture of the world, and ideology can become an obstacle.

The following advice by $D$. Carnegie can probably be attributed to a very specific one:

"The average person... can be led readily if you have his or her respect and if you show that you respect that person for some kind of ability" [21. P. 50]. 
Anyway, a weak linguistic personality - especially a public one — can be equated with a national disaster requiring the remedy of comprehensive measures to overcome this problem.

Let us summarize the main conclusions made by our study.

Practically at all speech-communicative levels, the linguistic personality [both as the author and the recipient of speech] reveals a set of idiostyle parameters that allow to characterize the linguistic personality as 1] weak; 2] averaged; 3] strong [elite]. For a communicative personality, the characteristics of the three main parameters motivational, cognitive and functional - are decisive.

The criteria of the most effective result of interpersonal communication can be recognized as genuine mutual understanding and joy, communicative comfort, intellectual, emotional and aesthetic empathy of communicants. Good command of such communicative universals and their appropriate use in interpersonal communication makes the language personality strong, as well as participation in intercultural communication contributes to the "cognitive flexibility" of the personality, enhancing its ability for analytical thinking, intercultural and linguocultural competence.

For a strong communicative personality, it is necessary not only to be able to speak correctly, but to communicate clearly and accessiblely to the addressee, to report, analyze, comment, summarize, parry, summarize, predict, which presupposes the existence of a developed thinking apparatus, as well as the lack of self-confidence, observance of the principles of cooperation, partnership, politeness and common culture - the presence of composure, emotional non-response to the attacks of the interlocutor. This person is aimed at effective communication in any situation, is able to make efforts to monitor its functioning and influence the interlocutor, to carry out feedback with him, the adjustment in case of failure to achieve the purpose of communication. This person is able to apply proper language functions and their combinations, communication strategies and tactics, protect himself from demands, requests, encroachments that harm their interests, create a positive image, show reflection, charm, maintain contact with the audience, calculate the closer and distant goals of communication, the interlocutor's reaction to the statement, status-situational roles. Suggestive potential, adaptability is also among the characteristics of a strong linguistic personality.

There is a list of such qualities and skills presented in D. Carnegie'a works which can be considered universal for a strong linguistic personality: active manifestation of personal interest, sincerity, goodwill and honesty in any interpersonal communication; the ability to evoke the emotions in listeners, appealing to their feelings, to saturate speech with emotional power; concreteness, rise and deep conviction; the ability to pass on their impulse to listeners; the fullest understanding of the interlocutor, a kind of penetration into his personality, plans and motives of speech; the ability to always speak calmly, very gently and friendly, not allowing any coercion and pressure. Often, open self-criticism becomes a shock absorber that can relieve tension in a dialogue, promote successful, conflict-free speech communication.

The most glaring signs of a weak linguistic personality are pronounced on the linguistic, communicative, paralinguistic, mental and intellectual levels. Even an elitist 
speech can characterize a weak linguistic personality due to the lack of targeted speech. In intercultural communication it is also possible to detect various manifestations of a weak linguistic personality — subjective [the interlocutors have a poor command of the language, are not inclined to mutual understanding, do not take into account the specifics of the situation, build their verbal and nonverbal behavior based on various cultural axioms] and objective [difference between "national consciousness" of communicants, the divergence of cultures, different division of conceptual space, goals and communicational strategies].

The idiostatic characteristics of a weak linguistic personality are: ignorance of the norms of various styles and genres of language and speech, forms of speech etiquette, speech poverty, lexical composition monotony, inability to listen to the interlocutor and adequately defend their point of view, aggressive tone, unpleasant voice, considerable presence of parasitic words, empty sounds that have no meaning, which indicates a lack of vocabulary, logical violations, lack of ability to read kinetic information, inability to talk in the right gauge, stiffness, fear of communication and the desire to avoid it, noisiness, fussiness, complacency, arrogance, officialese, use of words and phrases in inappropriate meanings, excessive use of foreign words, use of vulgar, obscene expressions, abuse, ridicule, criticism, analysis, hostility, non-use of praise and approval, inability to distinguish situations that require the use of suggestives and directives. A weak linguistic personality considers itself smarter and more significant than others. In turn, others avoid such a person, ignore him, laugh at him behind his back, or even despise him, consider him a fool; he may be downgraded.

The linguistic personality has both universal and specific national-cultural features. The same applies to the list of motivational reasons for the development of a strong linguistic personality. The main motives of the fact that Americans are striving to become a strong language personality, according to D. Carnegie, are the following: 1) prestige, the importance of being and feeling like a strong linguistic personality for almost all social levels of society; 2) the demand for a strong linguistic personality in business and everyday communication; 3) obtaining high wages, large incomes, expansion of production, commercial success; 4) the desire for leadership, the desire to stand out, to be seen among many other people, the achievement of maximum heights on the career ladder, the impact on others, self-promotion; 5) shortages in the education system of America (until the second half of the 50 s of the twentieth century); 6) the desire to get rid of the verbal communication fear; 7) improvement of intrapersonal self-perception and family relationships; 8) the desire to look decent in the eyes of others, consistent with the image of a cultured person; 9) the desire for self-improvement.

\section{CONCLUSION}

The results of our research [see also 34, 35] make it possible to predict the further study of parameters' transformation of a linguistic personality in dynamics (in particular, as from the second decade of the 21 st century) taking into account sociocultural characteristics, different situations of speech, interpersonal and intercultural communications. 
"His Majesty Personal Interaction (or Her Majesty Communication) governs people, their life, their development, and behavior, their knowledge of the world and themselves as part of this world. And any attempt to comprehend communication between people, to understand what prevents from it and what contributes, is important and justified, because communication is the tower, pivot, foundation of human existence" [36. P. 9]. Therefore, it is also necessary to create a clear classification of speech errors that corresponds to the modern understanding of the theory of communication.

\author{
(C) Olga A. Kadilina \& Elena N. Ryadchikova \\ Article history: \\ Received: 25.10 .2018 \\ Accepted: 1.11 .2018
}

\title{
REFERENCES
}

1. Budagov, R.A. (1976). New words and meanings In Man and his language. Moscow. (In Russ.).

2. Dryangina, E.A. (2006). The teacher's linguistic personality: to the problem statement In Language and thinking: psychological and linguistic aspects. Moscow-Ulyanovsk. pp. 219-220. (In Russ.).

3. Zvegintsev, V.A. (1964). The history of linguistics of the XIX-XX centuries in the essays and extracts. Part 1. Moscow. (In Russ.).

4. Kubryakova, E.S. (1994). Text and his understanding. Russian text, 2, 18-27. (In Russ.).

5. Khalyapina, L.P. (2005). Characteristics of the linguistic personality as a subject of communication. World in the language. Series of "Ethnogenesis and Ethnortoric", 11, 438-450. (In Russ.).

6. Ryadchikova, E.N. (2001). Speech image in cross-cultural perspective In Language and national images of the world. Maikop: ASU. pp. 19-21. (In Russ.).

7. Infantova, G.G. (2000). Strong linguistic personality: its permanent and variable signs In Speech. Speech activity. Text. Taganrog. pp. 63 -69. (In Russ.).

8. Carnegie, D. (1989). How to win friends and influence people. How to develop self-confidence and influence people by speaking in public. How to stop worrying and start living. Moscow: Progress.

9. Susov I.P. (1989). Personality as a subject of linguistic communication In Personal aspects of linguistic communication. Tver, 1989. (In Russ.).

10. Vinogradov, V.V. (1930). About fiction. Moscow. (In Russ.).

11. Bogin, G.I. (1986). Typology of text comprehension. Kalinin. (In Russ.).

12. Karaulov, Y.N. (1987). Russian language and language personality. Moscow. (In Russ.).

13. Krasnykh, V.V. (2001). Fundamentals of psycholinguistics and communication theory: Lecture course. Moscow: Gnosis. (In Russ.).

14. Thomas, L. (1989). The shortest path to fame In Dale Carnegie. How to win friends and influence people. How to develop self-confidence and influence people by speaking in public. How to stop worrying and start living. Moscow: Progress. pp. 21-33. (In Russ.).

15. Carnegie, D. (1992). The quick and easy way to effective speaking. NY: Dale Carnegie \& Associates Inc.

16. Golev, N.D. (2004). Linguistic personality and anthropotext in linguistics and linguodidactics [typological aspect] In Russian language: historical destinies and modern age: II Intern.

Congress of Russian Language Researchers. Moscow: Moscow State University named after MV Lomonosov. pp. 15-16. (In Russ.). 
17. Zelenskaya, V.V., Tkhorik, V.I. \& Golubtsov, S.A. (2000). The semantic dimension of personality according to the language [on the material of idioms] In Language personality: structure and evolution. Krasnodar: Kuban State University. pp. 188-202. (In Russ.).

18. Bezmenova, N.A. (1991). Essays on the theory of rhetoric's history. Moscow. (In Russ.).

19. Ledeneva, O.V. (2002). Speech culture as an ability to express one's thoughts In Problems of Applied Linguistics. Penza. pp. 121-123. (In Russ.).

20. Murzabekova, D.E. (2004). Linguistic means of creating harmonious interpersonal communication In Russian language: historical destinies and modernity: II Intern. Congress of Russian Language Researchers. Moscow: Moscow State University named after MV Lomonosov. pp. 131-132. (In Russ.).

21. Carnegie, D. (1981). How to Win Friends and Influence People. NY: Simon and Schuster.

22. Bogdanov, V.V. (1986). Communicative competence and communicative leadership In Language, discourse and personality. Tver: TSU. pp. 26-31. (In Russ.).

23. Sirotinina, O.B. (1998). Sociolinguistic factor in the development of the language personality In Language personality: sociolinguistic and emotive aspects. Volgograd-Saratov: Peremena. pp. 3 -9. (In Russ.).

24. Kiener, F. (1987). URL: http://www.dafont.com/frank-kiener.d1100.

25. Leontovich, O.A. (2002). Russians and Americans: paradoxes of intercultural communication. Volgograd. (In Russ.).

26. Urusova, O.A. (2005). Social features of the concept "America". World in the language. 11, 158-163. (In Russ.).

27. Abramova, T.V. (2000). National specificity of the culture in indirect speech acts of communication In Theoretical and applied linguistics. Issue 2. Language and social environment. Voronezh: VSTU. pp. 127-135. (In Russ.).

28. Kushcheva, O.Y. (2006). Language representation of the American national character In Modern linguistics: theory and practice. Materials VI Interlevel. Scientific methodological conf. Part II. Krasnodar: KVVAUL. pp. 3-7. (In Russ.).

29. Tyrnikova, N.G. (2003). Common and specifically national in speech etiquette (on the material of Russian and English languages): [dissertation]. Saratov. (In Russ.).

30. Shiryaeva, O. (2004). The word as a carrier of cultural information in artistic discourse In Language. Discourse. Text: Intern. Scientific conf. Rostov-n-D. pp. 215-216. (In Russ.).

31. Issers, O.S. (2002). Communicative strategies and tactics of the Russian language. Moscow: URSS. (In Russ.).

32. Malevinsky, S.O. (2008). Functional and speech structure of the personality and individual speech style In Functional and pragmatic features of units of different levels. Krasnodar: Kuban State University. pp. 118-129. (In Russ.).

33. Kostetskaya, A.G. (2001). Sociolinguistic characteristics of the speech of educated young people of Great Britain and the USA: [dissertation]. Volgograd. (In Russ.).

34. Ryadchikova, E.N. \& Kadilina, O.A. (2009). Organization of linguistic personality as a linguisticcommunicative phenomenon In Research in theoretical and applied linguistics. Krasnodar: Kuban State University. pp. 50-83. (In Russ.).

35. Ryadchikova, E.N. \& Kadilina, O.A. (2011). National-cultural specificity of an English-speaking strong language personality, Bulletin of Peoples' Friendship University of Russia. Series "Education issues: languages and specialty", 2, 103-107. (In Russ.).

36. Ter-Minasova, S.G. (2000). Language, Personality, Internet. Vestnik MGU. Series 19. Linguistics and intercultural communication, 4, 35-42. (In Russ.). 
УДК: 81'42:81'27

DOI: 10.22363/2313-2299-2018-9-4-859-882

\title{
СИЛЬНАЯ, СЛАБАЯ И УСРЕДНЕННАЯ ЯЗЫКОВАЯ ЛИЧНОСТЬ В КОММУНИКАТИВНО-ПРАГМАТИЧЕСКОМ И ЛИНГВОКУЛЬТУРНОМ АСПЕКТАХ
}

\author{
О.А. Кадилина ${ }^{1}$, Е.Н. Рядчикова ${ }^{2}$ \\ ${ }^{1}$ Российский университет дружбы народов \\ ул. Миклухо-Маклая, 6, Москва, 117198 \\ ${ }^{2}$ Кубанский государственный университет \\ ул. Ставропольская, 149, Краснодар, 350040
}

\begin{abstract}
Цель данного исследования - выявить перечень лингвистических, коммуникативных, прагматических и культурологических параметров, которые характеризуют сильную языковую личность, противоположную ей слабую языковую личность, а также обобщенно-усредненную языковую личность, и определяют их речевое поведение при речевой коммуникации. В связи с этим необходимо определить идиостилевые характеристики сильной языковой личности; установить знания и умения сильной языковой личности, могущие считаться универсальными, в межличностной и межкультурной коммуникации; рассмотреть национально-культурные особенности сильной языковой личности, принадлежащей англо-американской речевой культуре; выявить мотивы, ведущие к формированию англоговорящей сильной языковой личности; исследовать коммуникативные проблемы слабой языковой личности. Данные аспекты обусловили обращение в нашем исследовании к таким проблемам, как параметрирование и поведение языковой личности в межличностной и межкультурной коммуникации, поиски оптимальных вариантов речевого взаимодействия людей. В качестве иллюстративного материала привлекаются контексты из книг Д. Карнеги.
\end{abstract}

Ключевые слова: коммуникативная личность, сильная, слабая, усредненная языковая личность, коммуникативная компетенция, межличностное общение, воздействие, идиостилевые параметры, коммуникативное лидерство, национальная специфика общения

\section{БИБЛИОГРАФИЧЕСКИЙ СПИСОК}

1. Будагов Р.А. Новые слова и значения // Человек и его язык. М., 1976.

2. Дрянгина Е.A. Языковая личность педагога: к постановке проблемы // Язык и мышление: психологические и лингвистические аспекты. Мат-лы 6-й Всероссийской науч. конф. (Ульяновск, 17-20 мая 2006 г.) / Отв. ред. проф. А.В. Пузырев. М.-Ульяновск, 2006. C. $219-220$.

3. Звегинцев В.A. История языкознания XIX-XX веков в очерках и извлечениях. М., 1964. Ч. 1.

4. Кубрякова Е.С. Текст и его понимание // Русский текст. М., 1994. № 2. С. $18-27$.

5. Халяпина Л.П. Характеристика языковой личности как субъекта коммуникации // Мир в языке. Серия «Этногерменевтика и этнориторика» / отв. ред. Е.А. Пименов, М.В. Пименова. Вып. 11. Кемерово, 2005. С. 438-450.

6. Рядчикова E.H. Речевой имидж в кросс-культурной перспективе // Язык и национальные образы мира. Мат-лы Междун. науч. конф. (20-21 марта 2001). Майкоп: АГУ, 2001. C. $19-21$.

7. Инфантова Г.Г. Сильная языковая личность: ее постоянные и переменные признаки // Речь. Речевая деятельность. Текст: Межвуз. сб. науч. тр. / отв. ред. Н.А. Сенина. Таганрог, 2000. C. $63-69$.

8. Карнеги Д. Как завоевывать друзей и оказывать влияние на людей. Как вырабатывать уверенность в себе и влиять на людей, выступая публично. Как перестать беспокоиться и начать жить: Пер. с англ. / Общ. ред. и предисл. В.П. Зинченко и Ю.М. Жукова. М.: Прогресс, 1989. 
9. Сусов И.П. Личность как субъект языкового общения // Личностные аспекты языкового общения. Тверь, 1989.

10. Виноградов В.В. О художественной прозе. М., 1930.

11. Богин Г.И. Типология понимания текста. Калинин, 1986.

12. Караулов Ю.Н. Русский язык и языковая личность. М., 1987.

13. Kрасных B.B. Основы психолингвистики и теории коммуникации: Лекционный курс. М.: Гнозис, 2001.

14. Томас Л. Кратчайший путь к известности // Дейл Карнеги. Как завоевывать друзей и оказывать влияние на людей. Как вырабатывать уверенность в себе и влиять на людей, выступая публично. Как перестать беспокоиться и начать жить / Пер. с англ. 3.П. Вольской и Ю.В. Семенова. М.: Прогресс, 1989. С. 21-33.

15. Carnegie D. The quick and easy way to effective speaking. NY: Dale Carnegie \& Associates Inc., 1992.

16. Голев Н.Д. Языковая личность и антропотекст в лингвистике и лингводидактике (типологический аспект) // Русский язык: исторические судьбы и современность: II Междунар. конгресс исследователей русского языка (Москва: МГУ им. М.В. Ломоносова, $18-$ 21 марта 2004 г.): Труды и материалы. М.: МГУ, 2004. С. 15-16.

17. Зеленская В.В., Тхорик В.И., Голубцов С.А. Семантическое измерение личности по данным языка (на материале фразеологизмов) // Языковая личность: структура и эволюция: Монография. Краснодар: КубГУ, 2000. С. 188-202.

18. Безменова Н.А. Очерки по теории истории риторики. М., 1991.

19. Леденева О.В. Культура речи как умение выражать свои мысли // Проблемы прикладной лингвистики: Сборник материалов Всероссийского семинара (25 декабря 2002 г.). Пенза, 2002. C. $121-123$.

20. Мурзабекова Д.Е. Лингвистические средства создания гармоничного межличностного общения // Русский язык: исторические судьбы и современность: II Междунар. конгресс исследователей русского языка (Москва: МГУ им. М.В. Ломоносова, 18-21 марта 2004 г.): Труды и материалы. М.: МГУ, 2004. С. 131-132.

21. Carnegie D. How to Win Friends and Influence People. NY: Simon and Schuster, 1981.

22. Богданов B.B. Коммуникативная компетенция и коммуникативное лидерство // Язык, дискурс и личность. Тверь: ТГУ, 1990. С. 26-31.

23. Сиротинина О.Б. Социолингвистический фактор в становлении языковой личности // Языковая личность: социолингвистические и эмотивные аспекты. Волгоград-Саратов: Перемена, 1998. С. 3 -9.

24. Kiener F. 1987. URL: http://www.dafont.com/frank-kiener.d1100.

25. Леонтович O.A. Русские и американцы: парадоксы межкультурного общения. Волгоград, 2002.

26. Урусова O.A. Социальные признаки концепта «Америка» // Мир в языке. 2005. Вып. 11. C. $158-163$.

27. Абрамова T.B. Национальная специфика культуры общения в косвенных речевых актах // Теоретическая и прикладная лингвистика. Межвуз. сб. науч. тр. Вып. 2. Язык и социальная среда. Воронеж: ВГТУ, 2000. С. 127-135.

28. Кущева О.Ю. Языковая репрезентация американского национального характера // Современная лингвистика: теория и практика. Мат-лы VI Межвуз. научно-методич. конф. Ч. ІІ. Краснодар: КВВАУЛ, 2006. С. 3-7.

29. Тьрникова Н.Г. Общее и специфически национальное в речевом этикете (на материале русского и английского языков): автореф. дис. ... канд. филол. наук. Саратов, 2003.

30. Ширяева О.С. Слово как носитель культурной информации в художественном дискурсе // Язык. Дискурс. Текст: Междунар. науч. конф. Ростов н/Д, 2004. С. 215-216.

31. Иссерс О.С. Коммуникативные стратегии и тактики русской речи. М.: УРСС, 2002.

32. Малевинский С.О. Функционально-речевая структура личности и индивидуальный речевой стиль // Функционально-прагматические особенности единиц различных уровней: Сб. науч. статей. Краснодар: КубГУ, 2008. С. 118-129. 
33. Костецкая А.Г. Социолингвистические характеристики речи образованной молодежи Великобритании и США: автореф. дис. ... канд. филол. наук. Волгоград, 2001.

34. Рядчикова E.Н., Кадилина О.А. Организация языковой личности как лингво-коммуникативного феномена // Исследования по теоретической и прикладной лингвистике. Краснодар: КубГУ, 2009. С. 50-83.

35. Рядчикова E.H., Кадилина О.А. Национально-культурная специфика англоговорящей сильной языковой личности // Вестник Российского университета дружбы народов. Серия: Вопросы образования: языки и специальность. 2011. № 2. С. 103-107.

36. Тер-Минасова С.Г. Язык, личность, интернет // Вестник МГУ. Серия 19. Лингвистика и межкультурная коммуникация. 2000. № 4. С. $35-42$.

\section{Для цитирования:}

Кадилина О.А., Рядчикова Е.Н. Сильная, слабая и усредненная языковая личность в коммуникативно-прагматическом и лингвокультурном аспектах // Вестник Российского университета дружбы народов. Серия: Теория языка. Семиотика. Семантика, 2018. Т. 9. № 4. С. 859-882. doi: 10.22363/2313-2299-2018-9-4-859-882.

\section{For citation:}

Kadilina, O.A. \& Ryadchikova, E.N. (2018). Strong, weak and average linguistic personality in communicative-pragmatic and linguoculturological aspects. RUDN Journal of Language Studies, Semiotics and Semantics, 9(4), 859-882. doi: 10.22363/2313-2299-2018-9-4-859-882.

\section{Сведения об авторах:}

Кадилина Ольга Александровна, кандидат филологических наук, преподаватель ДПО / отделение иностранных языков / институт повышения квалификации и переподготовки; научные uнтересы: языковая личность, лингвокультурология, лингвопрагматика, языковая картина мира, язык автора, речевое воздействие, межличностная коммуникация, межкультурная коммуникация, национально-культурные особенности языковой личности; e-mail: olgakadilina@gmail.com

Рядчикова Елена Николаевна, доктор филологических наук, профессор кафедры общего и славяно-русского языкознания Кубанского государственного университета (г. Краснодар); научные интересы: речевая коммуникация, культура речи, теория языка, история языка, философия языка, воздействие речи, языковая логика, лингвокогнитивистика, лингвопрагматика, языковая личность, семантика, синтаксис, языковая картина мира, национальный менталитет, языковая репрезентация измененного состояния сознания, библеистика, афористика, лингвоконфликтология, лигвоментальная сфера, языковое сознание, языковое мышление, возможные миры; e-mail: e.n.ryadchikova@gmail.com

\section{Information about the authors:}

Olga A. Kadilina, Candidate of Philological Sciences, teacher of CPE / Department of Foreign Languages / Institute for Advanced Studies and Professional development; Research interests: linguistic personality, linguistic cultural studies, linguistic pragmatics, linguistic picture of the world, language of the author, verbal impact, interpersonal communication, intercultural communication, national and cultural features of the linguistic personality; e-mail: olgakadilina@gmail.com

Elena N. Ryadchikova, Doctor of Philology, Professor of the General and Slavic-Russian Linguistics Department of the Kuban State University (Krasnodar); Research interests: verbal communication, culture of speech, theory of language, language history, linguistic philosophy, impact of speech, linguistic logic, linguocognitivistics, linguopragmatics, linguistic personality, semantics, syntax, linguistic worldimage, national mentality, linguistic representation of an altered state of consciousness, biblical studies, aphoristics, linguistic conflictology, linguistic sphere, linguistic consciousness, linguistic thinking, possible worlds; e-mail: e.n.ryadchikova@gmail.com 